\title{
Culture conditions for the production of $\alpha$-galactosidase by Aspergillus parasiticus MTCC-2796: a novel source
}

\author{
Kumar Shivam \\ Department of Biotechnology \\ D.D.U. Gorakhpur University \\ Gorakhpur, India \\ Chandra Prakash Mani Tripathi \\ Department of Zoology \\ D.D.U. Gorakhpur University \\ Gorakhpur, India \\ Sarad Kumar Mishra* \\ Department of Biotechnology \\ D.D.U. Gorakhpur University \\ Gorakhpur 273009, India \\ E-mail: saradmishra5@rediffmail.com
}

Financial support: Deen Dayal Upadhyay Gorakhpur University, Gorakhpur, India.

Keywords: Aspergillus parasiticus, $\alpha$-galactosidase, culture condition, submerged fermentation.

Abbreviations: MTCC: microbial type culture collection

oNPG: o-nitrophenyl- $\alpha$-D-galactopyranoside

SmF: submerged fermentation

Aspergillus parasiticus microbial type culture collection (MTCC)-2796, a new source of $\alpha$-galactosidase is an efficient producer of enzyme in basic medium under submerged fermentation conditions. Maximum $\alpha$ galactosidase production $\left(156.25 \mathrm{Uml}^{-1}\right)$ was obtained when the basic medium is supplemented with galactose $(0.5 \% \mathrm{w} / \mathrm{v})$ and raffinose $(0.5 \% \mathrm{w} / \mathrm{v})$ as carbon source and yeast extract as nitrogen source. Enzyme production was also enhanced considerably in the presence of wheat bran $(1.0 \% \mathrm{w} / \mathrm{v})$. Enzyme secretion was strongly inhibited by the presence of $\mathrm{Hg}^{2+}, \mathrm{Cu}^{2+}$, and $\mathrm{Co}^{2+}$ in the medium and to some extent by $\mathrm{Zn}^{2+}$ and $\mathrm{Ni}^{+}$, while marginal increase in the enzyme production was observed when $\mathrm{Mg}^{2+}$ and $\mathrm{Mn}^{2+}$ were added in the medium. Among amino acids checked (aparagine, cysteine, glutamine, leucine and proline), glutamine (1 $\mathrm{mM}$ ) was found to be an enhancer for the enzyme production. The temperature and $\mathrm{pH}$ range for the production of enzyme were $25^{\circ} \mathrm{C}$ to $35^{\circ} \mathrm{C}$ and 6.5 to 7.5 , respectively with maximum activity $\left(50 \mathrm{Uml}^{-1}\right)$ at $30^{\circ} \mathrm{C}$ and pH 6.5 under static fermentation condition.

$\alpha$-Galactosidase ( $\alpha$-D-galactoside galactohydrolase, EC 3.2.1.22) is used for hydrolyzing the $\alpha$-galactosyl linkages present in simple raffinose family oligosaccharides as well as more complex polysaccharides (Manzanares et al. 1998). The wide specificity of hydrolytic action of $\alpha$-galactosidase finds its potential application in biotechnology: this enzyme is used to remove raffinose and to increase the yield of sucrose in beet sugar industry (Shibuya et al. 1995), to improve the gelling properties of galactomannans to be used as food thickners and to degrade the raffinose family sugars in food and feed materials (Guimarăes et al. 2001). Type B erythrocytes, which contain 3-O- $\alpha$-Dgalactopyranoside, can be converted into type $\mathrm{O}$ erythrocytes by exposure to $\alpha$-galactosidase (Goldstein et al. 1982). The deficiency of thermolabile lysosomal $\alpha$ galactosidase A causes Fabry's disease in human being (Breunig et al. 2003). $\alpha$-Galactosidase may be used in future for such purposes as enzymotherapy.

$\alpha$-Galactosidase is ubiquitous among microorganisms, plants and animals but mainly studied in seeds of plants. Among fungi, occurrence of $\alpha$-galactosidase is mainly reported from Aspergillus spp. (de Vries and Visser, 2001; Rezende et al. 2005).

Till date Aspergillus parasiticus was identified as a source of invertase (Mátrai et al. 2000) mainly, but in our laboratory after screening several selected Aspergillus spp., Aspergillus parasiticus microbial type culture collection (MTCC) 2796, which is reported to be isolated from the rizosphere of peanut, has been found to be an efficient producer of $\alpha$-galactosidase.

In view of the above $\alpha$-galactosidase applications and to

*Corresponding author 
make its production more economical, it is imperative to enhance the enzyme production under submerged fermentation $(\mathrm{SmF})$. In this report, we present optimal culture conditions for $\alpha$-galactosidase production by Aspergillus parasiticus MTCC-2796 under SmF in laboratory conditions.

\section{MATERIALS AND METHODS}

\section{Materials}

o-Nitrophenyl $\alpha$-D-galactopyranoside (oNPG) was obtained from Sigma Chemical Co. (St. Louis, MO, U.S.A.). Galactose, glucose, raffinose, melibiose, xylose, arabinose, yeast extract, malt extract, beef extract, peptone and all other chemicals used were of analytical grade purchased from Merck, India.

\section{Microorganism and culture medium}

Aspergillus parasiticus MTCC-2796 was obtained from Institute of Microbial Technology, Chandigarh, India. Fungal culture was maintained on Potato-dextrose-agar medium. The basal liquid culture medium for $\alpha$ galactosidase production was composed of $\mathrm{gl}^{-1} \mathrm{KH}_{2} \mathrm{PO}_{4} 7.0$, $\mathrm{K}_{2} \mathrm{HPO}_{4} \quad 2.0, \mathrm{MgSO}_{4} .7 \mathrm{H}_{2} \mathrm{O}$ 0.1, $\left(\mathrm{NH}_{4}\right)_{2} \mathrm{SO}_{4}$ 1.0, yeast extract 0.6 , and $1 \%(\mathrm{w} / \mathrm{v})$ of galactose, $\mathrm{pH} 6.5$. The $100 \mathrm{ml}$ Erlenmeyer glass flasks containing $25 \mathrm{ml}$ of culture medium were autoclaved at $121^{\circ} \mathrm{C}$ for $20 \mathrm{~min}$. These flasks were inoculated with fungal spores $\left(1 \times 10^{8} \mathrm{ml}^{-1}\right)$ and incubated at $30^{\circ} \mathrm{C}$ for 24 hrs in an automatic incubator. The assays were done in triplicate and the error bars present in the figure refer to the deviation obtained in the replicates.

\section{Optimization of culture conditions for maximal enzyme productivity}

The aim of optimization is to determine suitable conditions in order to obtain optimum yield of $\alpha$-galactosidase, the effect of various factors were tested as follows.

Effect of incubation time on $\alpha$-galactosidase production. To investigate the effect of different incubation time on $\alpha$-galactosidase production, fermentation was performed at $30^{\circ} \mathrm{C}$ in an automatic incubator and samples were prepared at every $12 \mathrm{hrs}$ interval (continuously for 4 days) for enzyme assay.

Effect of $\mathrm{pH}$, temperature and agitation on $\alpha-$ galactosidase production. To investigate the effect of $\mathrm{pH}$ on enzyme production, the initial $\mathrm{pH}$ of the basal medium was adjusted with $0.1 \mathrm{~N} \mathrm{HCl}$ and $0.1 \mathrm{~N} \mathrm{NaOH}$, in a $\mathrm{pH}$ range 2.0 to 10.0. The effect of incubation temperature on $\alpha$ - galactosidase production was investigated by incubating standard basal media with inoculums at different temperatures $\left(20^{\circ} \mathrm{C}, 25^{\circ} \mathrm{C}, 30^{\circ} \mathrm{C}, 35^{\circ} \mathrm{C}\right.$ and $\left.40^{\circ} \mathrm{C}\right)$ in an automatic incubator. Effect of agitation on enzyme production was determined by incubating the culture flasks inoculated with fungal spores in an automatic mechanical shaker for 24 hrs at $120 \mathrm{rpm}$ and then checked for extracellular $\alpha$-galactosidase production.

Effect of different carbon sources on a-galactosidase production. To investigate the effect of different carbon sources on $\alpha$-galactosidase production, galactose in the basal medium was replaced with $1 \%$ of raffinose, melibiose, arabinose, xylose and glucose separately, keeping constant the rest of the media composition.

The effect of combinations of raffinose $(0.5 \%)$ with galactose $(0.5 \%)$ and melibiose $(0.5 \%)$ with galactose $(0.5 \%)$ on $\alpha$-galactosidase production were also studied.

Effect of different nitrogen sources on a-galactosidase production. To investigate the effect of different nitrogen sources on $\alpha$-galactosidase production, yeast extract and ammonium sulphate in the basal medium were replaced with different organic (yeast extract, peptone, malt extract, tryptone and beef extract) and inorganic (ammonium sulphate and ammonium nitrate) compounds as nitrogen source, keeping rest of the media composition same. The concentrations of organic and inorganic compounds added in the medium were $0.1 \%$ and $0.3 \%$, respectively.

The effect of combination of yeast extract $(0.1 \%)$ and ammonium sulphate $(0.1 \%)$ was also studied.

Effect of metal ions on $\alpha$-galactosidase production. The effect of various metal ions $\left(\mathrm{Zn}^{2+}, \mathrm{Ni}^{2+}, \mathrm{Co}^{2+}, \mathrm{Ca}^{2+}, \mathrm{Mn}^{2+}\right.$, $\mathrm{Mg}^{2+}, \mathrm{Cu}^{2+}$ and $\mathrm{Hg}^{2+}$ ) on enzyme production was determined by adding $1 \mathrm{mM}$ metal salts to the basal fermentation medium (lacking $\mathrm{MgSO}_{4} .7 \mathrm{H}_{2} \mathrm{O}$ ).

Effect of different amino acids on a-galactosidase production. The effect of various amino acids (proline, asparagine, glutamine, cysteine and leucine) on enzyme production was determined by adding $1 \mathrm{mM}$ amino acid to the basal fermentation medium and checked for extracellular $\alpha$-galactosidase production.

Effect of various agricultural residues on $\alpha$ galactosidase production. To investigate the effect of various cheaper agricultural residues (wheat bran, Soy bean flour and Linum cake ) on $\alpha$-galactosidase production; the agricultural residues were added in the basal fermentation medium at a concentration of $1.0 \% \mathrm{w} / \mathrm{v}$ and checked for extracellular $\alpha$-galactosidase production.

\section{Crude enzyme extraction}

After an appropriate time of incubation, the culture supernatants were collected by filtration through filter paper (Grade 4B SD's cleardrop ashless filters). The filtrates were subjected to centrifugation (5000 rpm) for 10 $\min$ at $4^{\circ} \mathrm{C}$ and the obtained supernatant was used in the enzyme assay. 


\section{Enzyme assay}

$\alpha$-galactosidase assay was carried out in test tubes by the modified version of the method of Garro et al. (2004). The reaction mixture contained: $20 \mathrm{mM}$ oNPG $50 \mu \mathrm{l}$, McIlvaine buffer (pH 5.0) $50 \mu \mathrm{l}$, cell-free extract $100 \mu \mathrm{l}$; final volume: $200 \mu \mathrm{l}$. The mixture was incubated at $50^{\circ} \mathrm{C}$ for $10 \mathrm{~min}$, and the reaction was stopped by adding $3 \mathrm{ml}$ of sodium carbonate $(0.25 \mathrm{mM})$. One enzyme unit $(\mathrm{U})$ was defined as the amount of enzyme that released $1.0 \mu \mathrm{mol}$ of o-nitro phenol from its substrate oNPG per min under the given assay conditions. The results are expressed as $\mathrm{Uml}^{-1}$.

\section{RESULTS AND DISCUSSION}

\section{Effect of incubation time on $\alpha$-galactosidase production}

The effect of different incubation periods on $\alpha$ galactosidase production using basal fermentation medium is shown in Figure 1. The optimum production was obtained at 24 hrs while longer incubation time showed decreasing trend. The decline in total enzyme activity could be considered to be the result of inhibition of cellular functions due to depletion of nutritional factors from the growth medium, deactivation of the enzyme due to $\mathrm{pH}$ change or due to inducer exclusion. In literature, other species of Aspergillus such as A. fumigatus and A. foetidus have been reported to give maximum yield of $\alpha$ galactosidase after 36 and 144 hrs, respectively (Rezende et al. 2005; Liu et al. 2007). In this respect, A. parasiticus MTCC-2796 seems to be quite interesting, as it shows maximum enzyme production in less fermentation time.

\section{Effect of $\mathrm{pH}$, temperature and agitation on $\alpha-$ galactosidase production}

The effect of initial $\mathrm{pH}$ of the medium on enzyme production is shown in Figure 2. The optimum enzyme secretion was observed in the $\mathrm{pH}$ range 6.5-7.5. This optimum $\mathrm{pH}$ was little higher than that reported for $\alpha$ galactosidase producing strains of Penicillium sp. and $A$. foetidus (Wang et al. 2004; Liu et al. 2007).

Figure 3 shows the effect of incubation temperatures on $\alpha$ galactosidase production, which was investigated by incubating standard basal media with inoculum at different temperatures $\left(20^{\circ} \mathrm{C}, 25^{\circ} \mathrm{C}, 30^{\circ} \mathrm{C}, 35^{\circ} \mathrm{C}\right.$ and $\left.40^{\circ} \mathrm{C}\right)$; the highest production $\left(50 \mathrm{Uml}^{-1}\right)$ was achieved by growing the fungi at $30^{\circ} \mathrm{C}$. Longer fermentation time was required to attain maximal production when incubation was carried out at $20^{\circ} \mathrm{C}$ and $25^{\circ} \mathrm{C}$. The profile shows that increase in temperature above $35^{\circ} \mathrm{C}$ concomitantly decreases production of $\alpha$-galactosidase.

Agitation is an important parameter for adequate mixing, mass and heat transfer. To investigate the effect of agitation on $\alpha$-galactosidase production, inoculated culture flasks were incubated in an automatic mechanical shaker for 24 hrs. It was found that in agitated and non-agitated cultures the production of $\alpha$-galactosidase was 47.5 and $50 \mathrm{Uml}^{-1}$ respectively, showing marginal decrease in the enzyme production in agitated culture conditions. Lower activity in agitated culture can be attributed to the shearing forces generated during agitation.

\section{Effect of different carbon sources on a- galactosidase production}

The effect of various carbon sources on $\alpha$-galactosidase production is depicted in Figure 4. When carbon sources were used individually, the maximum enzyme production was obtained in the presence of galactose followed by melibiose and raffinose, but when combinations of galactose with melibiose and galactose with raffinose were used, the latter combination induced more enzyme production as compared to earlier one. It seems that the biosynthesis of $\alpha$-galactosidase was induced in the presence of galactose, raffinose and melibiose while other sugars had a very little influence on enzyme induction, showing that the specificity of $\alpha$-galactosidase is more for galactose, raffinose and melibiose than for others.

\section{Effect of different nitrogen sources on $\alpha$ - galactosidase production}

Influence of various nitrogen sources on $\alpha$-galactosidase production is depicted in Figure 5. Organic nitrogen sources such as yeast extract $(0.1 \% \mathrm{w} / \mathrm{v})$ and tryptone $(0.1 \% \mathrm{w} / \mathrm{v})$ supported good enzyme production but beef extract was found to be the best organic nitrogen source for $\alpha$-galactosidase production. Among the inorganic sources $0.3 \% \mathrm{w} / \mathrm{v}$ ammonium nitrate was found to be the best inorganic nitrogen source for enzyme production while $0.3 \% \mathrm{w} / \mathrm{v}$ ammonium sulfate supported only moderate level of enzyme production. However, a mixture of ammonium sulfate $(0.1 \% \mathrm{w} / \mathrm{v})$ and yeast extract $(0.1 \% \mathrm{w} / \mathrm{v})$ increased the enzyme production up to $57.3 \mathrm{Uml}^{-1}$. These observations reveal that a combination of organic and inorganic nitrogen sources induces higher $\alpha$-galactosidase production as compared to the isolated organic or inorganic nitrogen source.

\section{Effect of different metal ions on $\alpha$-galactosidase production}

Effect of various metal ions on $\alpha$-galactosidase production is shown in Figure 6. The production of $\alpha$-galactosidase was enhanced considerably by the presence of $\mathrm{Mn}^{2+}$ followed by $\mathrm{Mg}^{2+}$ and $\mathrm{Ca}^{2+}$, while $\mathrm{Zn}^{2+}, \mathrm{Co}^{2+}, \mathrm{Cu}^{2+}$ considerably inhibited the production whereas marginal inhibition was observed in the presence of $\mathrm{Ni}^{2+}$. Presence of $\mathrm{Hg}^{2+}$ ion completely inhibited the enzyme production. Not much information is available regarding effect of these trace elements on $\alpha$-galactosidase production.

Among the different cations, $\mathrm{Mg}^{2+}$ ion improved the secretion of $\alpha$-galactosidase into the medium; this may be attributed to its property of acting as effluxing agent. The 
involvement of this metal ion in membrane permeabilization and acting as ion channels has been well established (Karpen and Ruiz, 2002). Further, the decrease in the production of $\alpha$-galactosidase in the presence of $\mathrm{Zn}^{2+}$, $\mathrm{Co}^{2+}, \mathrm{Cu}^{2+}, \mathrm{Ni}^{2+}$ and $\mathrm{Hg}^{2+}$ may be attributed to their inhibitory effect on mycelial growth and proliferation (Yigitoglu, 1992) or possibly inhibition or inactivation of enzyme itself by these metals ions. Whereas the actual mechanism of stimulation or inhibition of metabolites is still not known (Ekwealor and Obeta, 2007).

\section{Effect of different amino acids on $\alpha$-galactosidase production}

The effect of amino acids on $\alpha$-galactosidase production is shown in Figure 7. Negligible enhancement was observed when proline and asparagine were supplemented in the basal fermentation medium while cysteine and leucine have no effect at all. The presence of glutamine $(1 \mathrm{mM})$ significantly enhanced the enzyme production, suggesting that the use of glutamine in the medium increases the biosynthesis of this enzyme.

\section{Effect of various agricultural residues on $\alpha$ - galactosidase production}

The effect of various agricultural residues on $\alpha$ galactosidase production was also studied, which is shown in Figure 8. The agricultural residues were added in the basic fermentation medium at a concentration of $1.0 \% \mathrm{w} / \mathrm{v}$. Among these, highest production $\left(98.75 \mathrm{Uml}^{-1}\right)$ of the enzyme was observed when wheat bran was supplemented, while marginal increase in the enzyme production was found in the presence of soybean flour in the medium. Slight decrease in the enzyme production was observed when Linum cake was supplemented. High enzyme production obtained by wheat bran is probably related with the presence of abundant galactooligosaccharides in it, which may act as an inducer for $\alpha$-galactosidase biosynthesis. This finding is important in view of the fact that by using wheat bran in the basal medium, the production of enzyme can be made more economical.

The laboratory-scale experiments may provide basis for finding out a process of $\alpha$-galactosidase production in SmF. Future research will be focused on optimizing the nutrient conditions to obtain higher biomass, which is desirable for the development of a low cost industrial process for $\alpha$ galactosidase production.

\section{ACKNOWLEDGEMENTS}

We acknowledge the support provided by Department of Biotechnology, Deen Dayal Upadhyay Gorakhpur University, Gorakhpur, India.

\section{REFERENCES}

BREUNIG, Frank; KNOLL, Anita and WANNER, Christoph. Enzyme replacement therapy in Fabry disease: clinical implication. Current Opinion in Nephrology and Hypertension, September 2003, vol. 12, no. 5, p. 491-495.

DE VRIES, Ronald P. and VISSER, Jaap.Aspergillus enzymes involved in degradation of plant cell wall polysaccharides. Microbiology and Molecular Biology Reviews, December 2001, vol. 65, no. 4, p. 497-522.

EKWEALOR, I.A. and OBETA, J.A.N. Effect of vitamins and bivalent metals on lysine yield in Bacillus megaterium. African Journal of Biotechnology, June 2007, vol. 6, no. 11, p. 1348-1351.

GARRO, Marisa S.; DE VALDEZ, Graciela F. and DE GIORI, Graciela S. Temperature effect on the biological activity of Bifidobacterium longum CRL 849 and Lactobacillus fermentum CRL 251 in pure and mixed cultures grown in soymilk. Food Microbiology, October 2004, vol. 21, no.5, p. 511-518.

GOLDSTEIN, J.; SIVIGLIA, G.; HURST, R.; LENNY, L. and REICH, L. Group B erythrocytes enzymatically converted to group $\mathrm{O}$ survives normal in $\mathrm{A}, \mathrm{B}$ and $\mathrm{O}$ individuals. Science, January 1982, vol. 215, no. 4529, p. 168-170.

GUIMARAES, Valeria Monteze; REZENDE, Sebastiâo Tavares de; MOREIRA, Maurilio Alves; BARROS, Everaldo Gonçalves de and FELIX, Carlos Roberto. Characterization of $\alpha$-galactosidase from germinating soybean seed and their use for hydrolysis of oligosaccharides. Phytochemistry, September 2001, vol. 58, no. 1 , p. 67-73.

KARPEN, Jeffrey W. and RUIZ, Maria Luisa. Ion channels: does each subunit do something on its own? Trends in Biochemical Sciences, August 2002, vol. 27, no. 8, p. 402-409.

LIU, Cai-Qin; CHEN, Qi-He; CHENG, Qian-Jun; WANG, Jin-Ling and HE, Guo-Qing. Effect of cultivating conditions on $\alpha$-galactosidase production by a novel Aspergillus foetidus ZU-G1 strain in solid-state fermentation. Journal of Zhejiang University SCIENCE B, April 2007, vol. 8, no. 5, p. 371-376.

MANZANARES, Paloma; DE GRAAFF, Leo H. and VISSER, Jaap. Characterization of galactosidases from Aspergillus niger: purification of a novel $\alpha$-galactosidase activity. Enzyme and Microbial Technology, April 1998, vol. 22, no. 5, p. 383-390.

MÁTRAI, T.; MAYER, S.; KÓKAI, S. and SALAMON, I. Invertase production of common moulds in food and feed grains as a possibility for rapid detection of Aspergillus flavus and Aspergillus fumigatus. International Journal of Food Microbiology, November 2000, vol. 61, no. 2-3, p. 187-191. 
REZENDE, Sebastião Tavares de; GUIMARAES, Valéria Monteze; RODRIGUES, Marília de Castro and FELIX, Carlos Roberto. Purification and characterization of an $\alpha-$ galactosidase from Aspergillus fumigatus. Brazilian Archives of Biology and Technology, March 2005, vol. 48, no. 2, p. 195-202.

SHIBUYA, Hajime; KOBOYASHI, Hideyuki; PARK, Gwi G.; KOMATSU, Yoko; SATO, Taku; KANEKO, Reiji; NAGASAKI, Hiroaki; YOSHIDA, Shigeki; KASAMO, Kunihiro and KUSAKABE, Isao. Purification and some properties of $\alpha$-galactosidase from Penicillium purpurogenum. Bioscience, biotechnology, and biochemistry, 1995, vol. 59, no. 12, p. 2333-2335.

WANG, C.L.; LI, D.F.; LU, W.Q.; WANG, Y.H. and LAI, C.H. Influence of cultivating conditions on the $\alpha$ galactosidase biosynthesis from a novel strain of Penicillium sp. in solid-state fermentation. Letters in Applied Microbiology, October 2004, vol. 39, no. 4, p. 369375.

YIGITOGLU, M. Production of citric acid by fungi. Journal of Islamic Academy of Sciences, 1992, vol. 5, no. 2, p. 100-106. 


\section{APPENDIX}

\section{FIGURES}

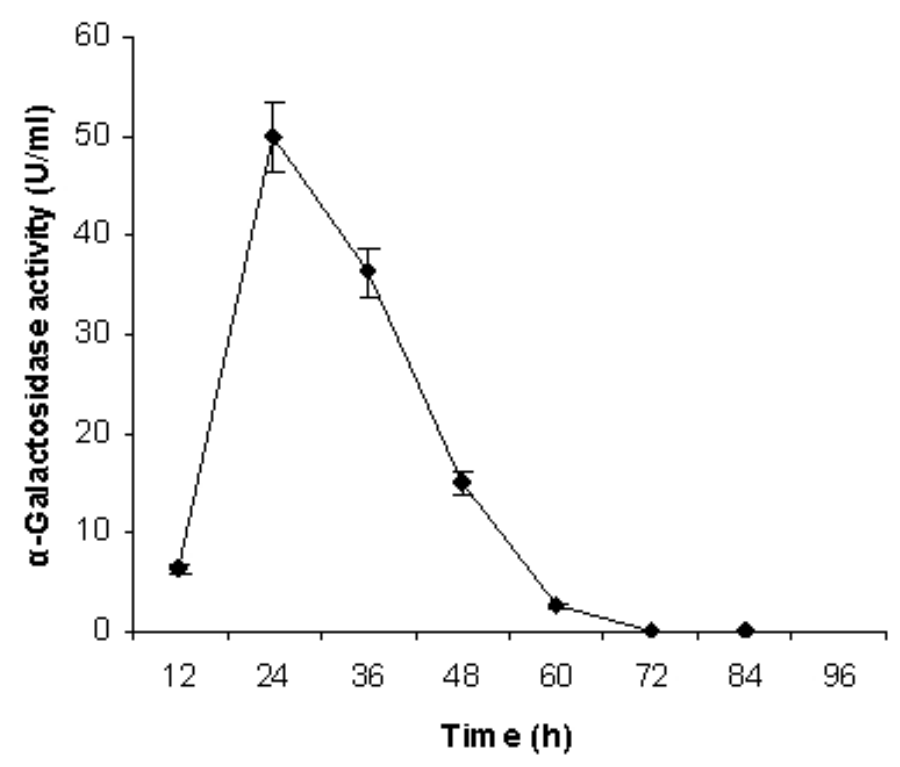

Figure 1. Effect of incubation time on $\alpha$-galactosidase production.

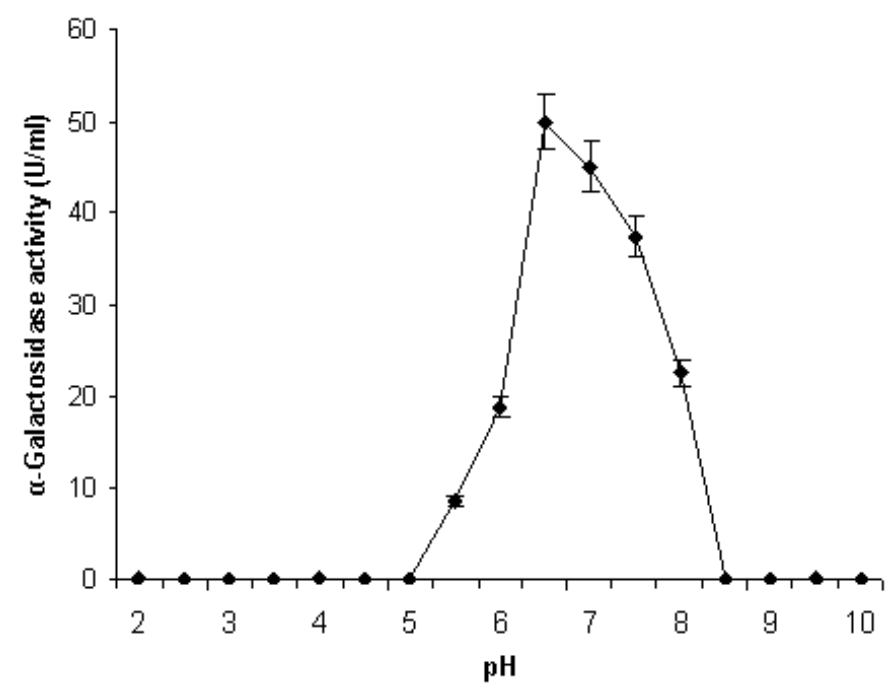

Figure 2. Effect of pH on $\alpha$-galactosidase production. 


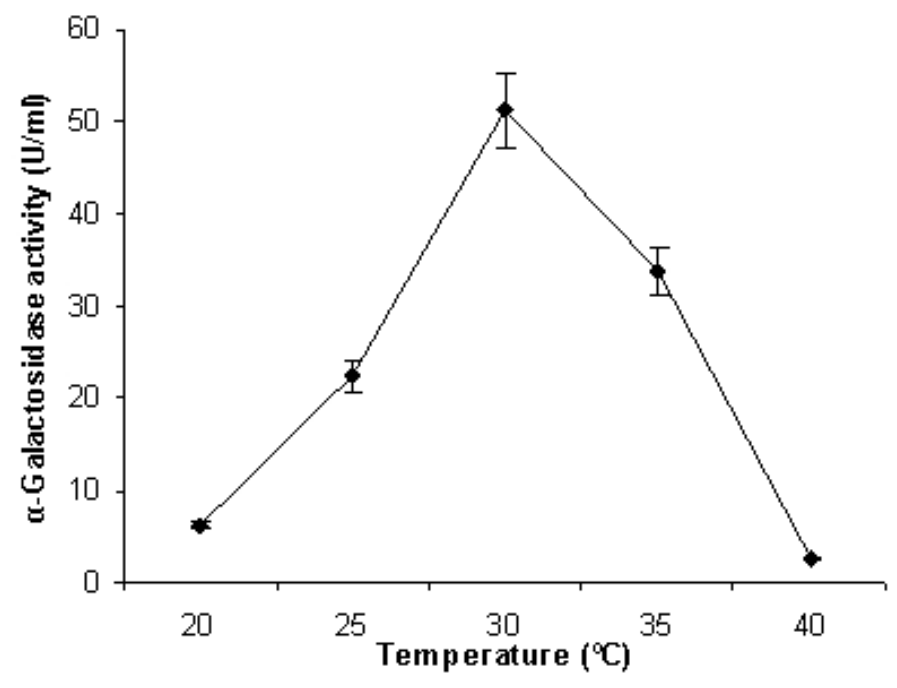

Figure 3. Effect of temperature on $\alpha$-galactosidase production.

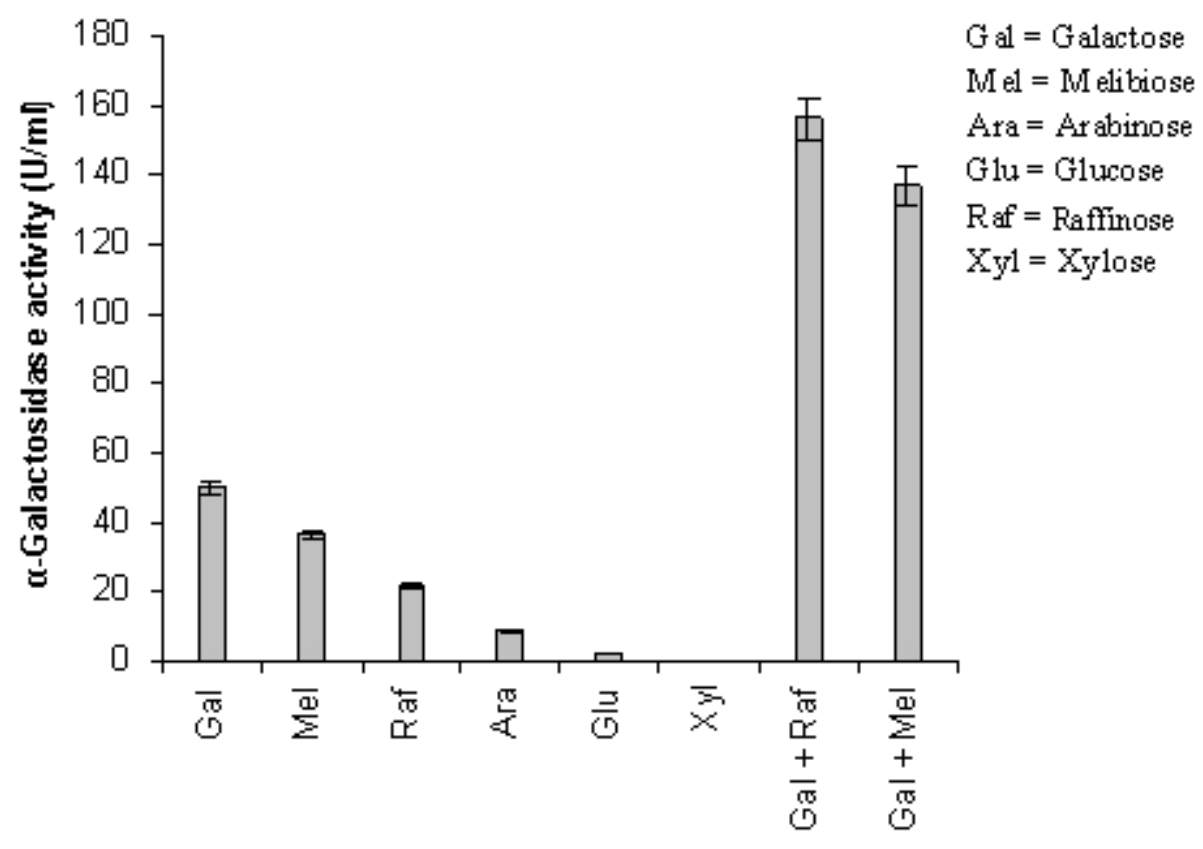

Figure 4. Effect of different carbon sources on $\alpha$-galactosidase production. 
Shivam, K. et al.

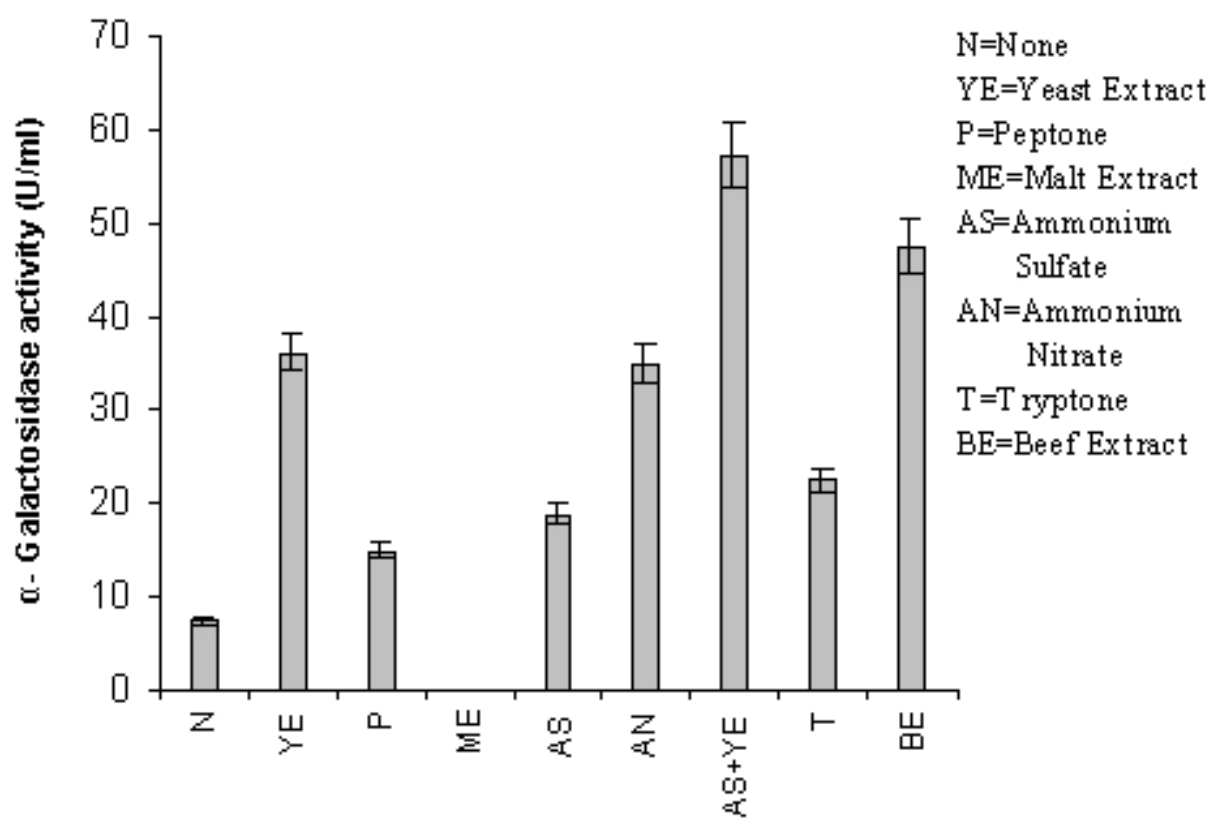

Figure 5. Effect of different nitrogen sources on $\alpha$-galactosidase production.

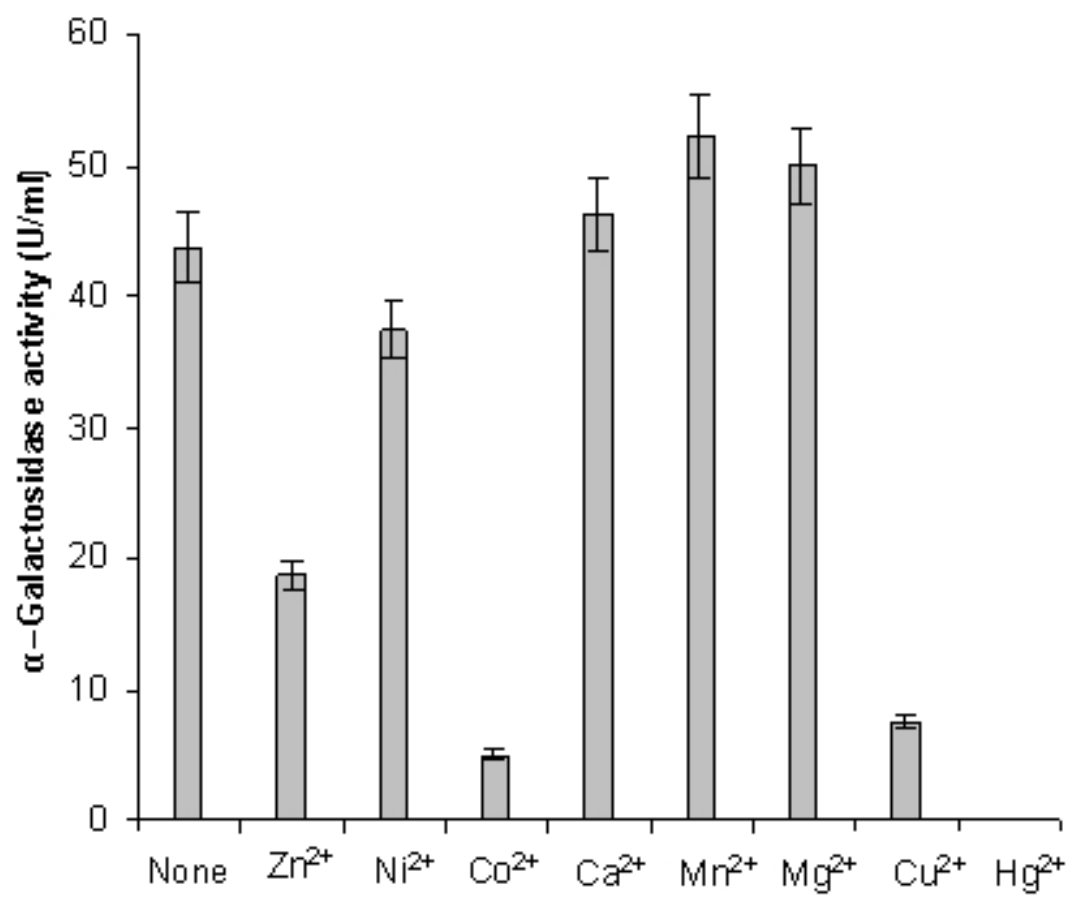

Figure 6. Effect of different metal ions (1 $\mathrm{mM})$ on $\alpha$-galactosidase production. 


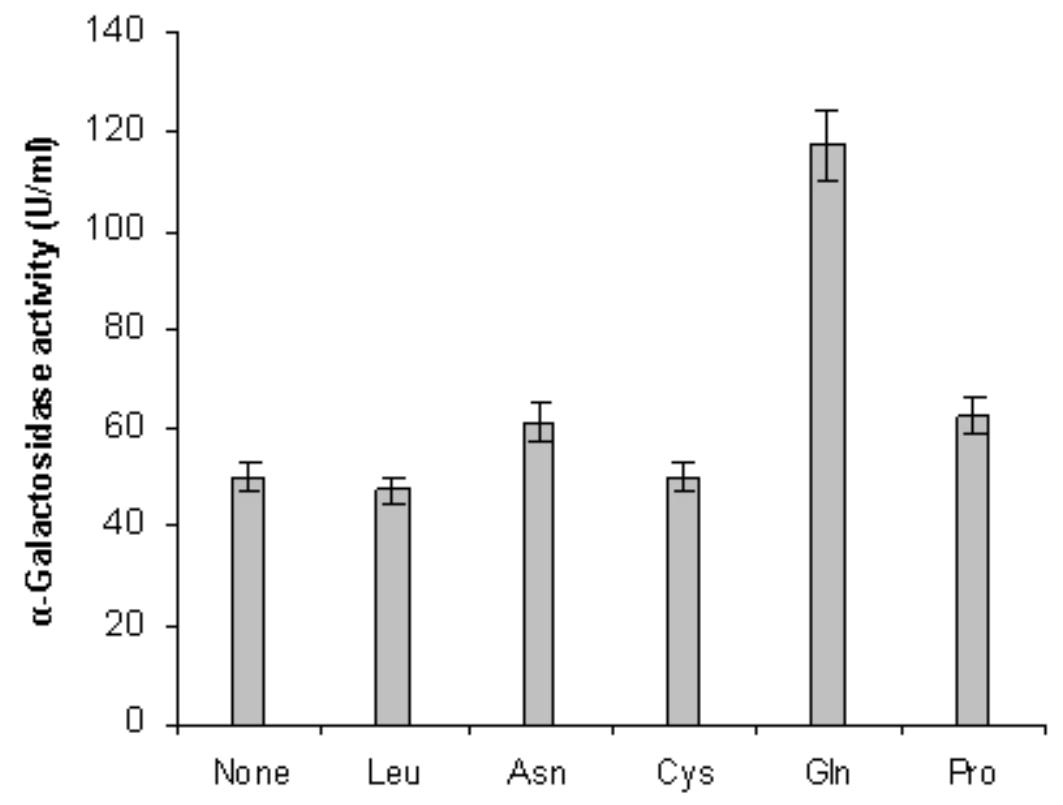

Figure 7. Effect of different amino acids $(1 \mathrm{mM})$ on a-galactosidase production.

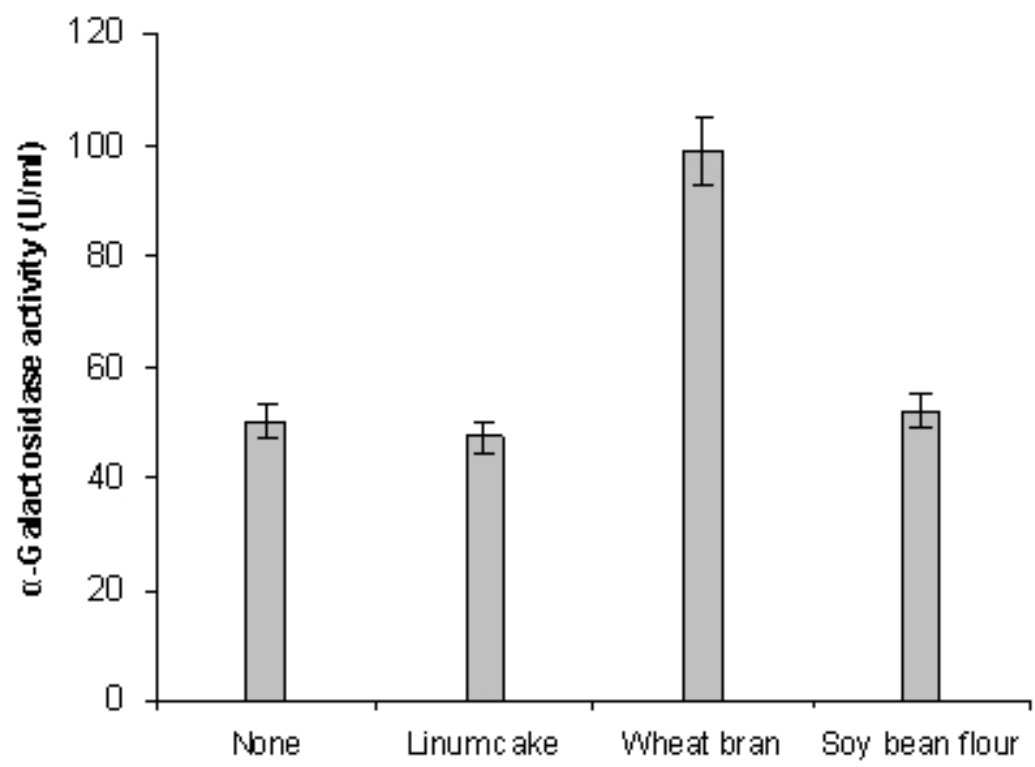

Figure 8. Effect of different agricultural residues $(1.0 \% \mathrm{w} / \mathrm{v})$ on $\alpha$-galactosidase production. 